\title{
TECHNOLOGIES OF INITIATING STUDENTS INTO INDEPENDENT (SELF-GUIDED) ACTIVITY IN SUPPLEMENTARY DISTANCE LEARNING
}

\author{
Dr. Irina V. Abakumova, Academy of Psychology and Educational of Southern Federal University, \\ Rostov-on-Don, Russia E-mail: abakira@mail.ru \\ Dr. Irina Al.Bakaeva, Academy of Psychology and Educational of Southern Federal University, \\ Rostov-on-Don, Russia E-mail: iabakaeva@sfedu.ru \\ Dr. Karina Yu. Kolesina, Institute of Languages and Literature, Journalism and Intercultural Communication of \\ Southern Federal University, \\ Rostov-on-Don, Russia E-mail: karina379@yandex.ru
}

\section{A R T I C L E I N F O}

Original Article

Received: November, 03.2016.

Revised: December, 14.2016.

Accepted: December, 16.2016.

doi:10.5937/IJCRSEE1602001A

UDK

37.018.43(470)"2016"

\section{Keywords:}

distance learning,

meaning-making,

technology,

competence,

cognitive motivation.

\section{A B S T R A C T}

The research in question investigates the technologies of initiating independent activity within the framework of distance learning and their psychological aspects. The authors' classification of educational technologies of initiating students into independent cognitive activity is presented. Such technologies utilize various psychological mechanisms of exciting students' cognitive interest, intensifying cognitive processes, developing independent activity skills, and, as a result, increase motivation for independent activity and learning on the whole. These include such types of technologies as developmental technologies, interactive technologies, technologies of information transfer, technologies of meaning-making initiation. The research of the attitude of distance learning educators to independent activity of students and the content of the academic courses were done at Moodle-based education programs. The findings show the differences in retention rate among distance learning educators whose competence in terms of initiating students into independent (self-guided) activity varies. It's emphasized that interactive lectures, videoconferences, audio-visual aids, interactive seminars, glossaries, interactive tests are considered the most efficient technologies in initiating students into independent (self-guided) activity. The obtained results have made it possible to stress the developmental effect of distance learning technologies and the technologies of initiating students into independent (self-guided) activity in various psychic spheres of students: cognitive, individual, emotional. We mention the changes in motivational sphere of students and their meaning-making activity. In the course of correct development of distance learning we notice the development of voluntary and nonvoluntary cognitive activity. A student starts actively participating in educational process, he becomes the creator of his own world.

(C) 2016 IJCRSEE. All rights reserved.

\section{INTRODUCTION}

Globalization as well as integration of modern resources sets new objectives for educators and educational psychologists in the area of open and distance learning, namely, Corresponding Author

Dr. Irina V. Abakumova, Academy of Psychology and Educational of Southern Federal University, Rostov-on-Don, Russia E-mail: abakira@mail.ru

\section{(c) (†) $\ominus$}

This work is licensed under a Creative Commons Attribution - NonCommercial - NoDerivs 4.0. The article is published with Open Access at www.ijcrsee.com in the research into the ways of having students engaged in independent (self-guided) activity as well as designing and providing new education technologies (Belousova A., G. Kozhukhar, L. Ryumshina, 2015; Abakumova I. V., 2011; Anson W., 2004; Asmolov A. G., 1999).

A. G. Asmolov has described the methodological guidelines for the development of education in XXI century, such as switching to the system of variable innovative technologies, ethnic differentiation of learning, variable coursebooks, multifunctional means of education, information technologies etc. (As- 
molov A. G., 2014). Supplementary education is becoming the pivot of new educational environment, turning the creative activity of school students into a resource for social development (Abakumova I. V, Ermakov P. N., Fomenko V. T., 2013).

The general trend towards expanding education boundaries until the removal of cultural, technological, and language barriers between students and teachers who may well belong to differing national, cultural and continental communities, sets new professional standards for educators and education professionals. The very idea of distance and open learning implies being open and being able to have a realistic and rational view of life. Hence, one of the key aspects is personality of an educator and their readiness to innovate (Azarova E. A., Mozgovaja N. N., Novokhatko E. N., 2015; Bakaeva I. A., Vanzha L. N., 2015; Bakaeva I. A., 2015).

Another party to the process of learning is students as the subjects of open and distance learning, being even more active participants of the process than those in the traditional classroom learning environment. At the same time, we can detect some changes in the way Russian school students show their psychological, cognitive and emotional readiness for such learning. The system of values undergoes transformation, with somatic and will-power values coming to the foreground and social and altruistic values fading into the background. The result is decline in initiative and lack of self-motivation. This means education professionals need to design some new technologies of initiating students into independent (self-guided) activity in the course of open and distance learning (Bakaeva I. A., 2015; Anson W., 2004; Rjumshina, L. I., 2000; Belousova A., G. Kozhukhar, L. Ryumshina, 2015).

The technologies of initiating students into independent (self-guided) activity embrace those activities of educators and students in the course of learning which are designed to develop students' capacity for unaided study in compliance with the principles of developing cognitive independence. Such technologies employ a certain set of activities, namely distance learning technologies.

The technologies of initiating students into independent cognitive activity have been formulated by I. V. Abakumova, I. A. Bakaeva on the basis of psychological aspects of initiating independent activity within the framework of distance learning. Such technologies utilize various psychological mechanisms of exciting students' cognitive interest, intensifying cogni- tive processes, developing independent activity skills, and, as a result, increase motivation for independent activity and learning on the whole (Table 1). These include such types of technologies as developmental technologies (technologies of working with texts, project technology, case-study); interactive technologies (corporate interaction, brainstorming, decision tree, simulation games, critical incident method, discussion); technologies of information transfer (technologies of audio-visual means of information delivery; working with textbooks); technologies of meaning-making initiation (creative-meaningful tasks, problem-based learning).

Table 1. Technologies of initiating students into independent (self-guided) activity in distance learning

\begin{tabular}{|c|c|c|c|}
\hline № & $\begin{array}{l}\text { Type of } \\
\text { technology }\end{array}$ & $\begin{array}{l}\text { Name of } \\
\text { technology }\end{array}$ & $\begin{array}{l}\text { Instrumentslforms within the distance } \\
\text { learning shell }\end{array}$ \\
\hline 1 & \multirow{3}{*}{ Developmental } & $\begin{array}{l}\text { Working } \\
\text { with texts } \\
\text { technology }\end{array}$ & $\begin{array}{l}\text { Taking notes when reading; annotated } \\
\text { reading (INSERT); conceptual dictionary } \\
\text { (glossary); drawing up a plan; essay; report }\end{array}$ \\
\hline 2 & & $\begin{array}{l}\text { Project } \\
\text { technology }\end{array}$ & $\begin{array}{l}\text { Interactive seminar; Wiki-project; } \\
\text { tasks for independent (self-guided) work }\end{array}$ \\
\hline 3 & & Case study & $\begin{array}{l}\text { Tasks for independent (self-guided) work; } \\
\text { chatroom; Wiki - portal }\end{array}$ \\
\hline 4 & \multirow{3}{*}{$\begin{array}{l}\text { Interactive: } \\
\text { Technologies of } \\
\text { team and group } \\
\text { interaction }\end{array}$} & $\begin{array}{l}\text { Corporate } \\
\text { interaction }\end{array}$ & Interactive seminar; chatroom; Wiki - portal \\
\hline 5 & & $\begin{array}{l}\text { Brainstor } \\
\text { ming }\end{array}$ & Videoconference; webinar; online chat room \\
\hline 6 & & $\begin{array}{l}\text { Decision } \\
\text { tree }\end{array}$ & $\begin{array}{l}\text { Videoconference; webinar; online chat room; } \\
\text { interactive seminar; Wiki - portal }\end{array}$ \\
\hline 7 & \multirow{2}{*}{$\begin{array}{l}\text { Interactive: } \\
\text { Technologies of } \\
\text { situation } \\
\text { modeling }\end{array}$} & $\begin{array}{l}\text { Simulation } \\
\text { games }\end{array}$ & $\begin{array}{l}\text { Custom-tailored games; real process models } \\
\text { (interactive laboratories etc.) }\end{array}$ \\
\hline 8 & & $\begin{array}{l}\text { Critical } \\
\text { incidents } \\
\text { method }\end{array}$ & $\begin{array}{l}\text { Tasks for independent (self-guided) work; } \\
\text { Assessment tasks - test materials }\end{array}$ \\
\hline 9 & $\begin{array}{l}\text { Interactive: } \\
\text { Technologies of } \\
\text { elaborating on } \\
\text { debating points }\end{array}$ & Discussion & $\begin{array}{l}\text { News forum; standard forum; informal } \\
\text { discussion; standard blog-format discussion; } \\
\text { Q\&A forum; chat-room }\end{array}$ \\
\hline 10 & \multirow[t]{2}{*}{$\begin{array}{l}\text { Technologies of } \\
\text { information } \\
\text { delivery }\end{array}$} & $\begin{array}{l}\text { Teaching } \\
\text { through } \\
\text { audiovisua } \\
\text { I means of } \\
\text { informatio } \\
\text { n delivery }\end{array}$ & $\begin{array}{l}\text { Presentations; digital textbook; hypertext on } \\
\text { the Internet; illustrative video- and audio- } \\
\text { materials; recorded audio-lectures; webinars }\end{array}$ \\
\hline 11 & & $\begin{array}{l}\text { Teaching } \\
\text { through } \\
\text { textbooks } \\
\end{array}$ & $\begin{array}{l}\text { Digital textbook; hypertext documents; } \\
\text { interactive lecture }\end{array}$ \\
\hline 12 & \multirow{2}{*}{$\begin{array}{l}\text { Technologies of } \\
\text { meaning- } \\
\text { making } \\
\text { initiation }\end{array}$} & $\begin{array}{l}\text { Creative- } \\
\text { meaningfu } \\
1 \text { tasks }\end{array}$ & $\begin{array}{l}\text { Tasks for independent (self-guided) work; } \\
\text { interactive seminar }\end{array}$ \\
\hline 13 & & $\begin{array}{l}\text { Problem- } \\
\text { based } \\
\text { learning }\end{array}$ & $\begin{array}{l}\text { Interactive lecture; interactive seminar; tasks } \\
\text { for independent (self-guided) work }\end{array}$ \\
\hline
\end{tabular}

\section{MATERIALS AND METHODS}

Teachers and students of Rostov Oblast Regional Center of Distance Learning for Gifted Children (RORCDLGC) acted as respondents in the course of research into the technologies of independent (self-guided) activity initiation. The Center offers Moodlebased supplementary education programmes for students of Rostov Oblast comprehensive schools. The research included finding out teachers' attitude to the technologies of independent (self-guided) activity initiation by asking them to fill in a questionnaire. Fol- 
lowing the completion of the questionnaire all the teachers were roughly divided into groups depending on the level of their competence (high and low) in employing the technologies of independent (self-guided) activity initiation. The content of distance learning courses designed by members of both groups was analyzed from the point of view of methods employed, and comparative analysis within both competence groups was carried out. School students were offered a questionnaire in order to evaluate the motivational aspect of distant learning process (Bakaeva I. A., 2015). In this case the retention rate was an indicator of how efficiently teachers from both competence groups worked.

On the whole the number of educators $\backslash$ professionals who acted as respondents amounted to 52 members of RORCDLGC teaching staff, with $81 \%$ of faculty members (university professors), 19\% of teachers from top comprehensive schools and other providers of supplementary education. All of the teaching staff $(100 \%)$ have a university degree, among whom $68 \%$ are Candidates or Doctors of Science. The teaching staff are in the 27 to 71 age range, with the average age being 38 . The length of teaching and research experience varies between 3 and 49 years, the average length of teaching experience being 15 years. The proportion of female to male respondents was $5 / 1$, with $85 \%$ of women, and $15 \%$ of men.

In order to differentiate between distance learning teachers in terms of their efficiency and attitude to the technologies they use, we employed the questionnaire designed by I. V. Abakumova, I. A. Bakaeva which focuses on the way teachers treat independent (self-guided) cognitive activity of school students. The questionnaires were then processed by means of content-analysis method including the following units of analysis: cognitive, emotional (evaluative) and behavioral.

\section{RESULTS}

After polling survey of the teachers and subsequent content analysis two groups of teachers were distinguished: "competent" and "lacking in competence" in terms of the use of technologies of independent (self-guided) activity of students. Out of the 52 teaching staff, 27 members were categorized as "competent" ones, while 25 - as "lacking in competence" (Table 2).
Table 2. Groups of distance learning teachers set up according to the teachers' attitude to the technologies of independent (selfguided) activity initiation

\begin{tabular}{|c|c|c|c|c|}
\hline Group & $\begin{array}{l}\text { Group } \\
\text { title }\end{array}$ & Group description & $\begin{array}{l}\text { Number of } \\
\text { respondents }\end{array}$ & $\begin{array}{c}\text { Student } \\
\text { retention } \\
\text { rate }\end{array}$ \\
\hline 1 & "Competent" & $\begin{array}{l}\text { Competent, } \\
\text { positive about and } \\
\text { actively } \\
\text { employing the } \\
\text { technologies of } \\
\text { independent (self- } \\
\text { guided) activity } \\
\text { initiation }\end{array}$ & 27 & $24.5 \%$ \\
\hline 2 & $\begin{array}{l}\text { "Lacking in } \\
\text { competence" }\end{array}$ & $\begin{array}{l}\text { Lacking in } \\
\text { competence, } \\
\text { ambivalent about } \\
\text { the technologies } \\
\text { of independent } \\
\text { (self-guided) } \\
\text { activity initiation, } \\
\text { using them on an } \\
\text { ad hoc basis }\end{array}$ & 25 & $16.4 \%$ \\
\hline
\end{tabular}

One of the practical tasks of research into the courses designed by distance learning teachers was to establish the student retention rate, as this is viewed as one of the most important issues in everyday practice of supplementary education. Statistical analysis has shown significant differences between the two groups in terms of student retention rate at $\mathrm{p}=0.01$ (U $=135)$ (Table 2). The retention rate was higher for the "Competent" group with the average of $24.5 \%$, while the average retention rate for the "Lacking in Competence" group was 16.4\%.

Content analysis in terms of the methods adopted by distance learning teachers has made it possible to draw up a list of technologies employed and the relationship between these (Table 3 ).

The study of the course elements in both groups enables us to see some differences, as the teachers from the "Lacking in Competence" group had them in greater number 175.33, with the average of 165.22 .

"Interactive lectures" which are employed as a resource of developmental technologies, technologies of information transfer and interactive technologies, were used much more extensively by the "Competent" teachers $(12.84 \%)$ than by the "Lacking in Competence" teachers $(5.52 \%$, with $\mathrm{Z}=0.548$ at $\rho \leq 0.01$ ), although these elements are actually basic to the process of initiating students into independent (self-guided) activity.

"Hypertext" documents containing embedded links which can be used to navigate the document interactively, play both developmental and initiating role in learning, and were used more extensively by the "Competent" teachers $(16 \%)$ than by the "Lacking in 
Competence" teachers $(12 \%$, with $\mathrm{Z}=0.348$ at $\rho \leq 0.01)$.

The biggest share across the groups, $18 \%$, was taken by videoconferences, with $11.6 \%$ in the "Lacking in Competence" group $(Z=0.395$ at $\rho \leq 0.01)$ and $10.7 \%$ in the "Competent" group. This fact indicates, that the "Lacking in Competence" teachers are much more geared to following the traditional "classroom period" system of teaching, in which the teacher plays the leading role, with the student being just an object of pedagogic effort. At the same time, polling both teachers and students enabled us to make a conclusion that a rationally balanced combination of videoconferences and independent (self-guided) activity results in most productive learning and development of students' cognitive motivation.

Such technologies of information delivery as video-materials are used on average by the "Competent" teachers at $15.82 \%$ of the course, whereas the average percentage of $12.86 \%$ of the course used by the "Lacking in Competence" group is significantly lower for the course in question $(Z=0.376$ at $\rho \leq 0.01)$.

Audio-materials are used on average by the teachers of both groups at $8 \%$ of the course, which is explained by the subject area taught, because it is the courses of foreign language and social studies that employ audiol video-materials and video-lectures most often.

The courses designed by distance learning teachers also utilize some elements of interactive technologies, namely - test materials. These are introduced as instrumentally developed standardized means of assessment which can be used both by a student at any convenient time and by a teacher whenever

Table 3. Analysis of the way educational technologies are represented in the courses designed by distance learning teachers

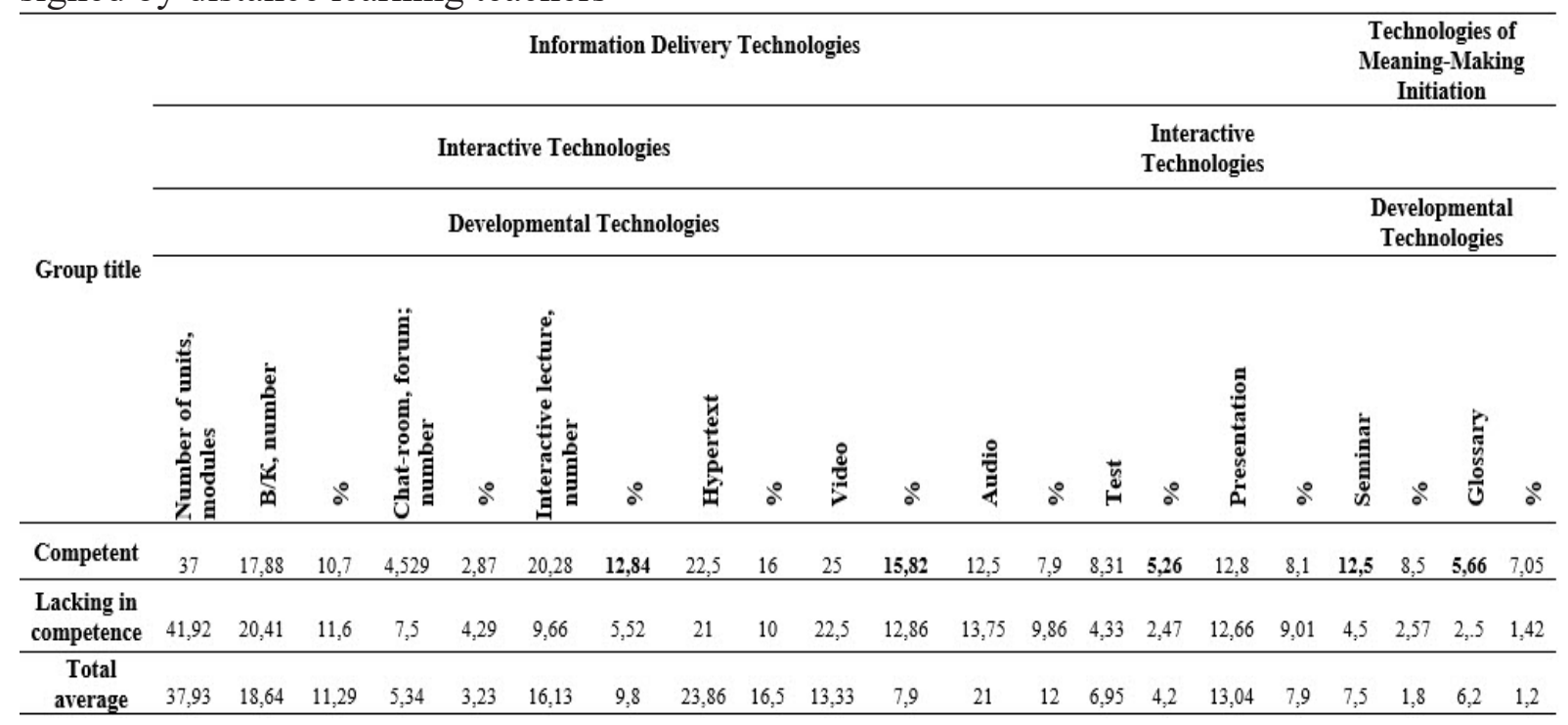

wWw.ijcrsee.com the latter chooses to run a planned check on the students' progress within a strictly limited period. The "Competent" teachers' test materials make up $5.26 \%$ of the overall number of tasks, while the test materials employed by the "Lacking in competence" teachers make up $2.47 \%(Z=0.413$ at $\rho \leq 0.01)$ of the overall number of tasks, which indicates a higher level of interactivity in the courses of the former group.

Some fairly significant differences were also perceived in the extent to which technologies of meaning-making initiation were represented, such as interactive seminar and glossary. These elements have a complex structure, and are produced cooperatively by teachers and students in a single creative effort, which brings about a new creative product resulting from the study of a unit or a module. According to statistical data, 8.5\% of the "Competent" teachers' materials were represented in the form of interactive seminar, while the percentage of the same category of materials designed by the "Lacking in competence" teachers was only $2.57 \%(Z=0.414$ at $\rho \leq 001)$. Content-analysis of this element of the course testifies to the fact that the latter is very labour-intensive and introducing it into the course requires taking a number of factors into account. However, there is no doubt that it has a strong meaning-making effect as well as impact on the students' cooperation.

Glossary as an element of the course was used in $7.05 \%$ of the "Competent" teachers' materials, whereas the percentage was $1.42 \%$ in the "Lacking in competence" teachers' materials $(Z=0.611$ at $\rho \leq 0.01)$. 


\section{DISCUSSION}

Theoretical and empirical analysis of the obtained results has made it possible to outline the basic psychological features of employing the technologies of independent (self-guided) activity initiation in distance learning:

1) Two groups of teachers are involved in the implementation of distance education: "competent" and "lacking in competence". "Competent" teachers demonstrated considerable knowledge of technologies of independent (self-guided) activity, knew their way around the issue in question, provided comprehensive explanatory statements on school students' independent (self-guided) activity, could enumerate the technologies used to initiate independent (self-guided) activity, shared their experience of employing such technologies, and, at the same time, had a positive attitude to these technologies and, moreover, practice the technologies of initiating independent (self-guided) activity in their everyday work. "Lacking in competence" teachers did not show enough competence in the theory of independent (self-guided) activity technologies, had an ambivalent attitude to employing these technologies and used them only on an ad hoc basis.

2) The level of competence of teachers in the use of technologies affects the level of formation of independent activity of students in distance education.

3) Technologies facilitate such functions as cognitive function, teaching function, communicative function, educational (instructional) function, regulatory function, cultural function, prestige (status) function, forecast function.

4) The developmental effect of distance learning technologies is brought about by individualized instruction and learning, closer cooperation with the teacher, enhanced efficiency in acquisition of knowledge, which becomes more personalized as a result (Kazakova T. V. Basalaeva N. V. Hramova L. N. Zaharova T. V. Jakovleva E. N., 2015).

5) The learning environment in distance education acts as a means of human memory and awareness enhancement, and, as it is, shapes the form in which individual awareness and memory exist. Internal processes are given outward expression, and vice versa. The very teaching-learning process is actually a pattern of intellectual activity on the whole, and this activity obviously structures intellectual functions and enables us to identify, objectivize and study them.
6) The research in question emphasizes the fact that distance learning technologies are viewed as active teaching aids which shape well-rounded personalities and perform a number of functions helping to form the child's picture of the world: cognitive function, teaching function, communicative function, educational (instructional) function, regulatory function, cultural function, prestige (status) function, forecast function. The process of distance learning, which on the surface looks "impersonal" and "formalized", possesses some deep structure with an enormous potential to develop students: to shape productive, creative thinking functions, to develop intellectual ability, to form operational thinking and personality motivation structure, to develop self-organization skills, to ensure personal development through character development.

7) Distance learning, due to independent (self-guided) work, brings about certain changes in the students themselves, with the ensuing enhanced interest in self-education, better diligence and single-mindedness, selfcontrol and will-power. The introduction of technologies of independent (self-guided) activity initiation develops students' creativity due to the creative forms of this activity, implying "digesting" the material in a personalized way and creating a new product. 


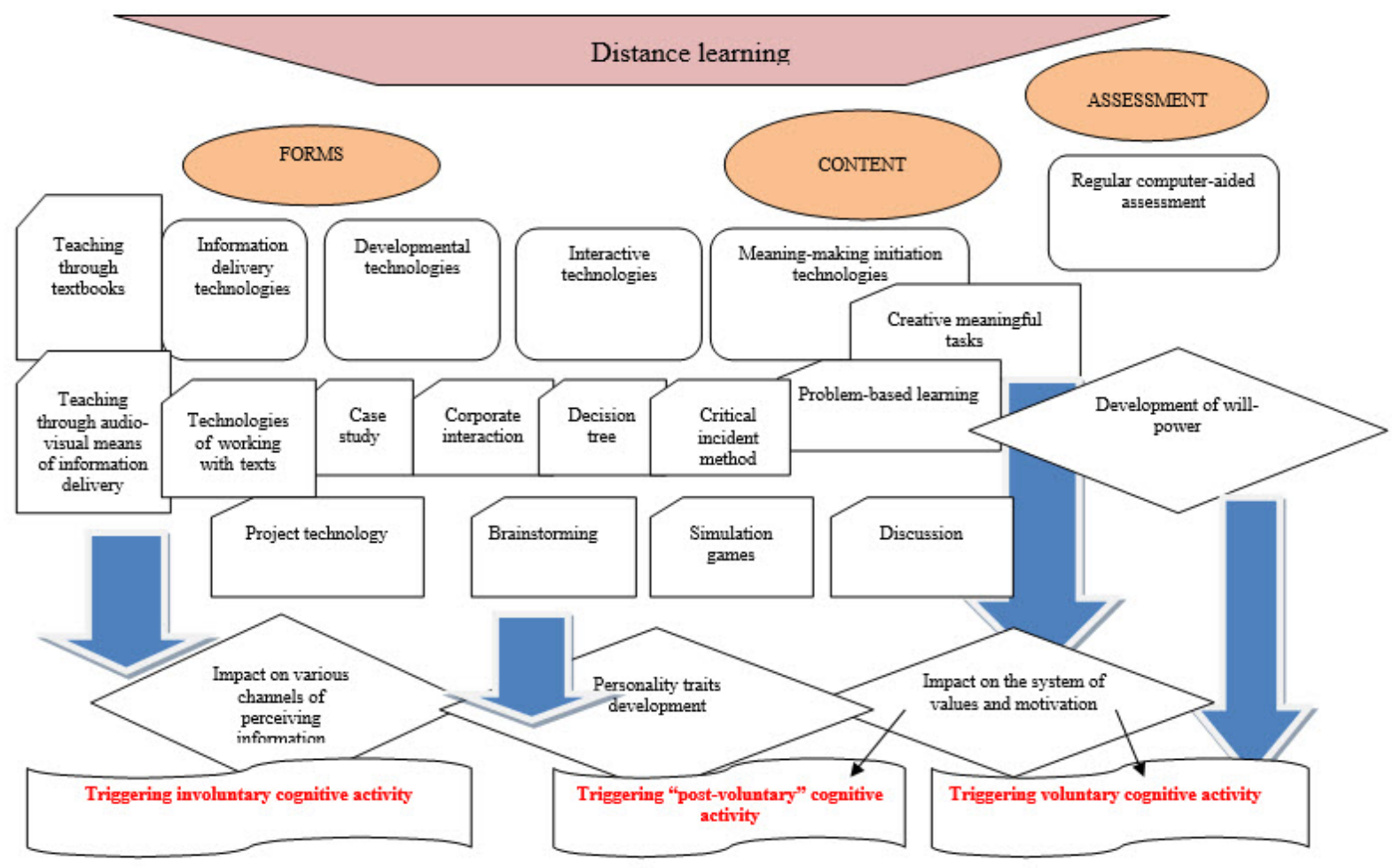

Figure 1. A chart outlining cognitive independence initiation in distance learning

\section{CONCLUSION}

1. Initiation of independent (self-guided) activity by means of various technologies, such as information transfer technologies or developmental technologies, exerts effect on various channels for the perception of information, which initiates involuntary cognitive activity. Such interactive technologies as brainstorming, corporate interaction, simulation games cause personality changes and help develop personality traits, as well as producing educational and developmental effect.

2. Application of such meaning-making technologies as creative-meaningful tasks, problem-based learning, discussion methods focused on the system of values, involves initiation of higher levels of motivation which are linked to the students' personal meanings. As a result, students deem learning and knowledge acquisition necessary, and this triggers post-voluntary cognitive activity.

3. Assessment plays an important role in distance learning, being an indispensable element of guided learning. Regular computeraided assessment helps students to develop self-control and self-assessment, which, in turn, triggers voluntary cognitive activity.

4. Taking advantage of information technologies in distance learning activates other psychological mechanisms. Thus, higher proportion of independent (self-guided) activ- ity and lower proportion of teacher-guided activity enable teachers to make their guidance much more focused. By communicating with the student, the teacher sets out the guidelines, while the student chooses their path to achieve the goal. As a result, active participation in one's own learning process helps the student to increase their self-esteem and self-assessment.

5. Within the framework of distance learning which involves both learning through radio and TV and the use of the available telecommunication channels, the teacher-student link happens to be closer, as, on the one hand, it is more accessible in terms of time and space, and on the other, it is more individualized and personalized, which facilitates the initiation of students' cognitive activity as well. Developing students' creativity through creative-meaningful tasks is an important feature of distance learning.

6 . Despite the fact that the process of distance learning looks "impersonal" and "formalized" on the surface, it actually possesses some deep structure with an enormous developmental potential. However, researchers still disagree about the subject matter and scope of distance learning and distance education, as well as the choice of methods, means, technologies which possess a greater potential to develop, encourage and motivate, so that students' personalities could successfully de- 
velop in the course of distance learning.

7. The "Competent" teachers, compared to the "Lacking in competence" ones, were found to have been employing a wider range of methods, means and course elements in terms of independent (self-guided) activity initiation technologies. At the same time, the percentage of interactive lectures, interactive seminars, glossaries and test tasks, - interactive, developmental and aimed at initiating students' meaning-making, - was much higher relative to the percentage of other types of tasks in the course. "Lacking in competence" teachers showed indifference to distant learning issues and had lower percentage of tasks aimed at initiating students into independent (self-guided) activity, although they were much more focused on the thorough teacherstudent information delivery using videoconferences and video materials, which indicates that even in the distance learning process these teachers attach more weight to the traditional role of a teacher.

\section{ACKNOWLEDGMENTS}

This work was supported by a grant of SFU № 213.01-11 / 2016-2NM (Ministry of Education task № 28.125.2016 / NM) “Research and improvement of the political and legal mechanisms of tolerance among the students in a multicultural society."

\section{REFERENCES}

Abakumova I. V, Ermakov P. N., Fomenko V. T. (2013). Novodidaktika. Kniga 1. Metodologiya i Tekhnologii obucheniya: $\mathrm{v}$ poiskakh razvivayuschego resursa [New Didactics. Book 1. Methodology and Teaching Technologies: in search of developing resource]. T. M.: CREDO Publishers, 162.

Abakumova I. V. (2011). Smyslodidaktika. [The didactics of meaning]: Uchebnik dlja magistrov psihologii i pedagogiki [A textbook for masters of psychology and pedagogy] [Text].2-d ed. M.: CREDO Publishers, 449.

Anson W. (2004). Effects of teaching self-monitoring in a distance learning course. Doctoral thesis, University of Southern California, USA.

Asmolov A. G. (1999). Psihologija XXI veka i rozhdenie variativnogo obrazova-tel'nogo prostranstva Rossii [Psychology of XXI century and advent of variable educational environment]. Mir psihologii [The World of Psychology], 1, 198-208.

Asmolov A. G. (2014). Dopolnitel'noe personal'noe obrazovanie $\mathrm{v}$ 'epohu peremen: sotrudnichestvo, sotvorchestvo, samotvorenie [Supplementary personal education in the time of change: co-operation, co-creativity, self-making]. Obrazovatel'naja politika [Educational policy],
2(64), 2-6.

Asmolov, A. G., \& Asmolov, G. A. (2009). From wemedia to I-media: Identity transformations in the virtual world. Psychology in Russia: State of the art, 2(1).

Azarova E. A., Mozgovaja N. N., Novokhatko E. N. (2015). Representation of students on the modern Russian teacher. Mediterranean Journal of Social Sciences. 6(5), 1. MCSER Publishing, Rome-Italy.

Bakaeva I. A. (2015). Tekhnologii initsiatsii samostoyatelnoj deyatelnosti uchaschikhsya $\mathrm{v}$ sisteme distantsionnogo obrazovaniya [Technologies of initiating students into independent (self-guided) activity in the system of distance learning ]. I. V. Abakumova, I. A. Bakaeva, V. M. Golubova, A. Y. Moskalenko. Izvestiyay uzhnogo federalnogo universiteta. Pedagogicheskie nauki [Proceedings of Southern Federal University. Pedagogic Sciences], 12. 139-147.

Bakaeva I. A., Vanzha L. N. (2015). The Study of Personality Profile of Distance Education Teacher. Russian psychological journal. 12(3), 16-33.

Belousova A., G. Kozhukhar, L. Ryumshina. (2015). Innovative Teaching Methods in Adult Education. 8th International Conference of Education, Research and Innovation. Seville, Spain. IATED. P. 4046-4050.

Kazakova T. V. Basalaeva N. V. Hramova L. N. Zaharova T. V. Jakovleva E. N. (2015). Specifika pedagogicheskogo vzaimodejstvija $\mathrm{v}$ kontexte ontopedagogicheskoj obrazovatel'noj modeli [Unique features of pedagogic interaction in the context of onto-pedagogic educational model]. Sovremennye problemy nauki $i$ obrazovanija [Contemporary issues of science and education], 3, 480.

Rjumshina, L. I. (2000). Empirical study of pedagogical activity styles. Voprosy psikhologii, 1, 142-149. 